\title{
THE USE OF OPEN SPACES AND SOCIAL ISSUES IN PUBLIC HOUSING IN SÃO PAULO, BRAZIL
}

- Case study of Cingapura project -

\author{
ブラジル・サンパウロにおける公営住宅のオープンスペース利用と社会問題
}

シンガプラプロジェクトの事例研究

\author{
Viviane Raquel ITO*, Dongyun KWAK ** and Toshio KITAHARA*** \\ イトウヴィヴィアネラケル，郭＼cjkstart東＼cjkstart潤，北原理 雄
}

\begin{abstract}
Cingapura Project is an example of the Brazilian attempt to solve the problem of favelas, or slums, in São Paulo city that did not succeed. Cingapura Project's effort focused on satisfying the most urgent needs of the low socioeconomic population without regard for the non-physical aspects of favelas. The open spaces of Cingapura Project's developments do not allow for the development of healthy and sociable communities. They neither promote the integration of the developments with their vicinities, nor the inclusion of their residents in the city.
\end{abstract}

Keywords: Public Housing, Open Spaces, Communities, Social Issues

公共住宅,オープンスペース,コミュニティ,社会問題

\section{Introduction}

The favela has been an object of extensive research in Brazil, however, there have been a few discussions about the policies of Cingapura Project, whether it was effective or not in solving the housing issues in São Paulo city and the results of its disregard of economic, social and physical factors. Cities Alliances discussed the achievements of Cingapura Project and its housing policies ${ }^{6}$. According to their findings, the unit cost was higher than other similar slum upgrade projects. As a result, only half of the favelas targeted for intervention received partial solutions and many families continued living in precarious conditions around the new developments. The residents had to face a new range of problems and expenses they did not have in favelas. The consequence was a high default rate among inhabitants of the new developments (64.5\% in 2002). Cities Alliances criticized São Paulo's municipal housing policies for its quantitative and short-term solutions, leading to the segregation of its low-income groups. Abiko and Pereira focused their analysis in Zaki Narchi, the first development of Cingapura Project ${ }^{2}$. According to their survey, Zaki Narchi's residents were satisfied with the improvement in their living conditions, formal address and housing. However, there were complaints about noise and inappropriate behaviour due to the lack of orientation and preparation of the residents to live in the new developments: they had to adapt to a new lifestyle, learning how to share spaces, respect the privacy of others and maintain their common spaces. There was a general concern about safety-residents had requested the installation of electronic gates at the entrance of the blocks and the construction of walls surrounding the development. Residents were also concerned about their economic sustainability and supply of products and

services-there was a request for the regularization of 30 commercial businesses as a result of the lack of provision of commercial areas in the development. According to S. Rodrigues, the organization of the communities began to weaken from the moment the inhabitants of favelas were relocated into the temporary accommodations for the construction of the new housing developments ${ }^{13)}$. Many families were against being relocated, and many of them lost their furniture and belongings in the process. Families who did not live in favelas moved into these accommodations with the hope of benefitting from the programme. Rodrigues analysed Imigrantes, one of Cingapura Project's developments. Many families did benefit from the project and live now in better conditions. The new development resulted in an increase in land prices in the surrounding areas. However, it did not result in the economic or social ascent of the residents of that particular favela who did not plan to live in the development for a long time. According to Ito, the injection of US\$220 million of development funds into the economy aided local economic growth $^{8}$. Ito criticizes the single residential use given to the developments-it destroyed the commercial activities that had existed in favelas and guaranteed the income and supply of products and services to many families. Many residents lost their primary source of income and were no longer able to support their families; they also lost access to commercial services and shops. In addition, the idea of delivering the apartments without the proper finishing with the purpose to engender a sense of belonging and ownership failed as many of the residents never finished their apartments and still live in provisional conditions. Apuzzo criticized Cingapura Project

\footnotetext{
* Ph. D. Candidate, Graduate School of Engineering, Chiba University, M. Phil.

* Assistant Prof., Department of Engineering, Chiba University, Dr. Eng.

*** Prof., Department of Engineering, Chiba University, Dr. Eng.
}

千葉大学大学院工学研究科 博士後期課程 $\cdot$ 修士 $($ 学術 $)$

千葉大学大学院工学研究科 助教・博士 (工学

千葉大学大学院工学研究科 教授. 工博 
for focusing its efforts only in the residential aspects of its new developments, not allowing the participation of the inhabitants in its planning process ${ }^{3}$. According to Apuzzo, the division of favelas and the distribution of their communities into apartments and buildings closed the open spaces, where most of the public social relations developed in favelas, resulting in the loss of their social life in the city.

This paper investigates the use of open spaces and the social implications on the lives of the residents of a Cingapura Project development. Review of past studies, analysis of a case study and a survey of its residents were part of this investigation process. This study helps in the clarification of the issues São Paulo faces in the provision of public housing and highlights the importance of well-planned and designed open spaces which better integrate and serve residents both socially and economically with their surrounding areas.

\subsection{Transitional Spaces - from Private to Public}

Transitional spaces can enhance the integration of private and public spaces. According to Gehl, the integration of an individual with the city starts from home and gradually spreads outwards ${ }^{7}$. This gradual transition between the building and the built environment gives people a greater feeling of security and a stronger sense of belonging to the areas outside the private residence as it attenuates the transition between private and public spaces, encouraging people to stay in closer contact with the areas outside their homes and participate in the activities that take place in the open spaces

Firstly, home is a private place where a family gathers and develops private social relations. Semi-private spaces such as balconies and the entrance to one's home are the intermediary spaces between inner and outer spaces. The common spaces in a housing development or in a neighborhood promote the integration of residents amongst themselves. Semi-public spaces make the transition between housing developments and their surroundings, making the connection of the developments with the city, and vice versa, easier. Finally, public services, commerce and public facilities allow for the integration of an individual with the city. Developments that consider that can more successfully provide good quality housing for their residents.

\section{Context}

\subsection{São Paulo - Housing Issues}

The provision of public housing for low socio economic groups is a serious issue in São Paulo, Brazil's largest city and main economic and financial hub. Cortiço and favela are São Paulo's most common types of slums. Scarce resources and the lack of proposals, which are able to transcend the electoral cycles and be implemented on the necessary scale, affect the development of long term housing policies in São Paulo ${ }^{6}$. The lack of effective housing policies resulted in a sharp increase of favelas in São Paulo.

A favela is a group of dwelling units, built of wood, zinc, tin, cardboard or even bricks, randomly distributed on illegally occupied land, which are often located in hilly areas or riverbanks ${ }^{1}$. They are "a physical and spatial manifestation of urban poverty ${ }^{15}$ ): a representation of ineffective housing policies provided by the state ${ }^{11)}$. They usually have little infrastructure or facilities in their vicinity. They are cramped, irregular and their streets and walkways are narrow, making the access difficult for vehicles.

The first favelas appeared in São Paulo as a result of the housing crisis in 1940 when the low socio-economic population refused to move to the outer areas of the city and started to occupy empty land in central areas ${ }^{5}$. They were unnoticed until 1970, when the population of favelas reached one percent of the population in São Paulo city ${ }^{14}$. They changed the pattern of centre-periphery segregation in São Paulo. Until then, lower socio-economic groups lived either in the poor conditions of cortiços in central areas (but paying rent), or on the periphery having to commute long hours to and from work $^{4)}$.

Home ownership became a symbol of economic security as economic instability and inflation discouraged most people from renting a property in Brazil. Self-built dwellings were the housing alternative found by low socioeconomic groups to achieve home ownership ${ }^{12)}$.

Due to Brazil's economic recession, inflation and the population's impoverishment, the population of favelas increased sharply during the 1980s. There was a significant improvement in living conditions in favelas over the 70s and 90s. Dwellings, once built of wood were being built by bricks and had often more than one floor. Most of them (96.8\%) had access to treated water, power $(82.2 \%)$ and public transport $(81.5 \%)$. Favelas had changed from a provisional housing arrangement into a more permanent type of housing. During the $90 \mathrm{~s}, 52 \%$ of the population's differential growth was absorbed by São Paulo's favela population. The population of favelas reached $19.8 \%$ of the city population when Cingapura Project was established in $1994^{4}$ ). (See distribution of favelas throughout São Paulo in fig. 1)

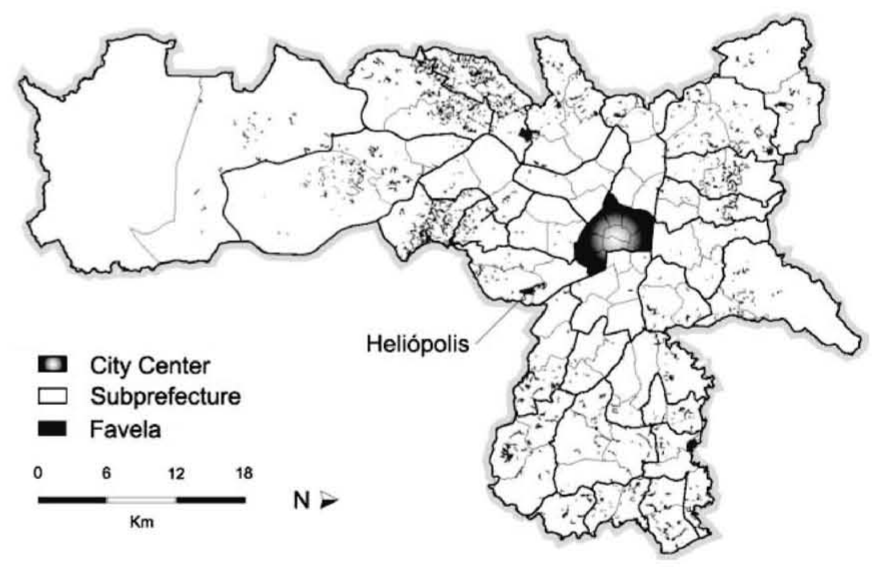

Fig. 1 Location of Favelas in São Paulo Cityi)

\section{Cingapura Project}

The Cingapura Project was the brand name given to PROVER (Favela Verticalization Programme for the Municipality of São Paulo). It began in 1994 and continued through 2000. Financed by the Inter-American Development Bank, with an overall investment of approximately US\$220 million, it aimed, at the end of 72 months, to provide 30,000 apartments to the inhabitants of favelas through the construction of vertical housing ${ }^{6}$.

Cingapura Project's main purpose was to provide housing to favela inhabitants and use existent infrastructure, as a large number of favelas in 
São Paulo are located in areas with sufficient infrastructure ${ }^{13)}$. It intended to respect the identity the inhabitants of favelas had with the area they lived in building the developments in the same locations. It aimed to allow its inhabitants to participate in the process of creating a home for themselves and to promote identity and pride by giving them the responsibility to finish and furnish their apartments ${ }^{8)}$.

At the conclusion of Cingapura Project, 14,595 housing units were delivered in only half of the favelas targeted for intervention. The programme was criticised for not achieving its objectives, and for its reliance on a traditional and high-cost model of construction and building management ${ }^{()}$. Cingapura Project was stopped in 2000. Due to high rates of default (close to $80 \%$ ) in the payment of fees by residents, by 2005 , the Housing Department of São Paulo city established the 3Rs Program (Land Regularization, Credit Recuperation and Development Revitalization) in order to restore and maintain the developments. ${ }^{\text {ii) }}$ (See list of Cingapura Projects in table 1 and their locations in fig. 2)

Table 1 List of Cingapura Project Developmentsiii)

\begin{tabular}{llll}
\hline No. & Project & & \\
\hline 1 & Agua Branca & 16 & Lidiane I \\
2 & Chácara Bela Vista & 17 & Miguel Estefano \\
3 & Chaparral & 18 & Morro da Esperança \\
4 & Chaparral / Tiquatira & 19 & Parque Novo Mundo / Vila Maria \\
5 & City Jaragua & 20 & Piqueri \\
6 & Dom Macario & 21 & Raul Seixas \\
7 & Edu Chaves & 22 & Samaritá \\
8 & Goiti & 23 & São Francisco - Area 5 \\
9 & Haia do Carrão & 24 & São Francisco - Cachoeira / Benfica \\
10 & Heliopolis L2 & 25 & São Francisco - Coruja do Campo \\
11 & Imigrantes & 26 & São Francisco - Hidrosfera \\
12 & Jardim Imperador & 27 & São Francisco - Morro das Pedras \\
13 & Jardim Maninos & 28 & Trivelato \\
14 & Jardim Maraial & 29 & Vila Nilo \\
15 & José Paulino dos Santos & 30 & Zaki Narchi
\end{tabular}

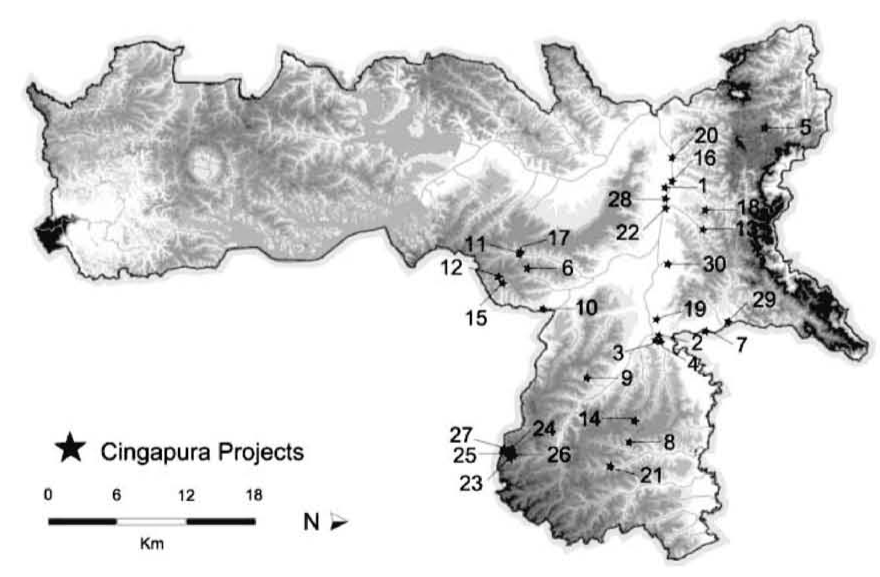

Fig. 2 Location of Cingapura Projects in São Paulo Cityiv)

\section{Analysis}

4.1 Heliópolis L2 Housing Estate

Heliópolis L2 Housing Estate is one of Cingapura Project developments.
It is located in Cidade Nova Heliópolis, in the southeast of São Paulo city. Cidade Nova Heliópolis contains São Paulo's largest favela, Heliópolis, which has approximately 125,000 inhabitants. The development project in Heliópolis was divided into smaller projects in order to be successfully accomplished.

This paper investigates Heliópolis L2 Housing Estate because it is part of São Paulo's largest favela, relatively close to the city center with a considerably strong community willing to improve their communal spaces.

Heliópolis L2 Housing Estate has 30 blocks of 5 floors each-a total of 600 apartment units. Bounded to the north by forest, another public housing development to the southwest, and a river followed by a major thoroughfare to the southeast, the development is physically isolated from other parts of the city. These boundaries protect the development from outsiders but at the same time, make it difficult for the residents to access services and facilities available in other parts of the city. The development site is triangular (fig. 3). The buildings are arranged in lines parallel to each other forming long, wide spaces used for the circulation of cars and as car parking spaces. Parking spaces, initially open, have been fenced in to prevent car thefts (fig. 6). Some residents use these spaces to run small, illegal businesses such as hair salons, groceries, or bars (fig. 7). ${ }^{\mathrm{v})}$

These improvised constructions, including the new shanty housing that has encroached on the north side of the development degrade the open spaces of Heliópolis L2 Housing Estate (fig. 8). They are even more aggravated by the lack of maintenance due to high rates of default on fees and bills and the little attention given to durability and maintenance of the development.

Heliópolis L2 Housing Estate's open spaces lack gathering points, facilities and furniture: there are no water fountains, toilets, sheltered spaces, or green areas. Besides the physical degradation of its open spaces, crime and security are another issue in Heliópolis L2 Housing Estate. Parts of the development are controlled by criminals and avoided by the residents. The entrance to the blocks was fenced in by residents (fig. 5). This created a semi-public transitional space between the roads and building interiors. The apartments were not provided with a balcony or any other space to make the transition between inner and outer spaces less abrupt. The lack of these intermediary spaces results in conflicts among some families.

The social activities that happened in the open spaces of the favela now happen inside the apartments or in the improvised garages in Heliópolis L2 Housing Estate (fig. 7). There are no places for recreation within the development besides the degraded sports court. There are no movie theaters, libraries or anything to provide the residents of Heliópolis L2 Housing Estate with entertainment in the surrounding areas either. The community centre works in an improvised construction in the neighbor development. Most children from Heliópolis L2 Housing Estate attend one of the two schools in the neighborhood. They walk to school and play in the streets or at the playground located in the neighbour development which is in poor condition and does not accommodate all the children from both developments9). Families consider their situation in Cingapura Project transitory, hoping to move into a better place. 


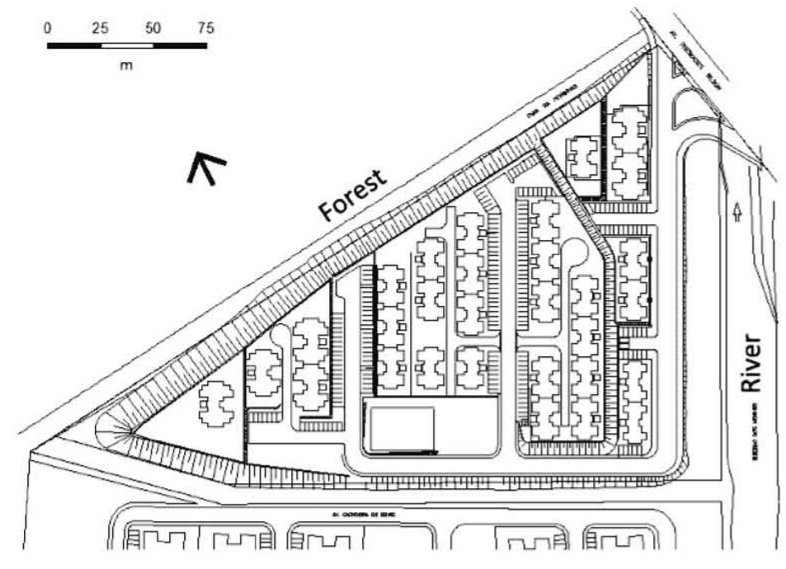

Fig. 3 Site Plan of Heliópolis L2 Housing Estate ${ }^{\mathrm{vi})}$

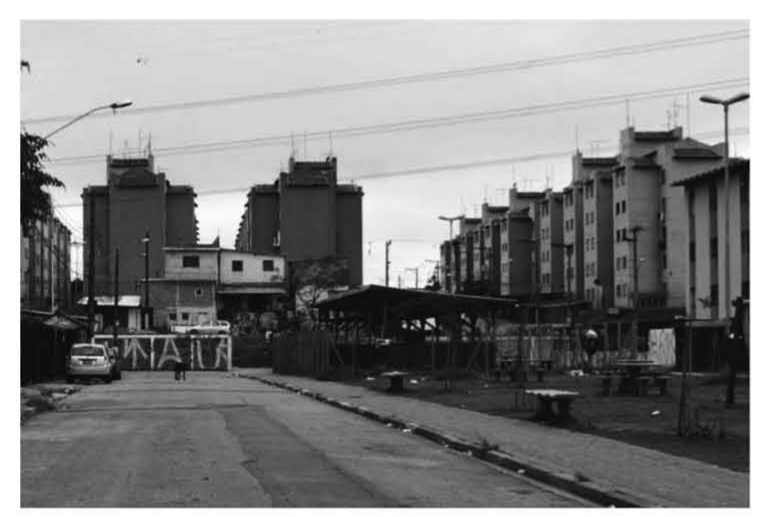

Fig. 4 Heliópolis L2 Housing Estate in the background

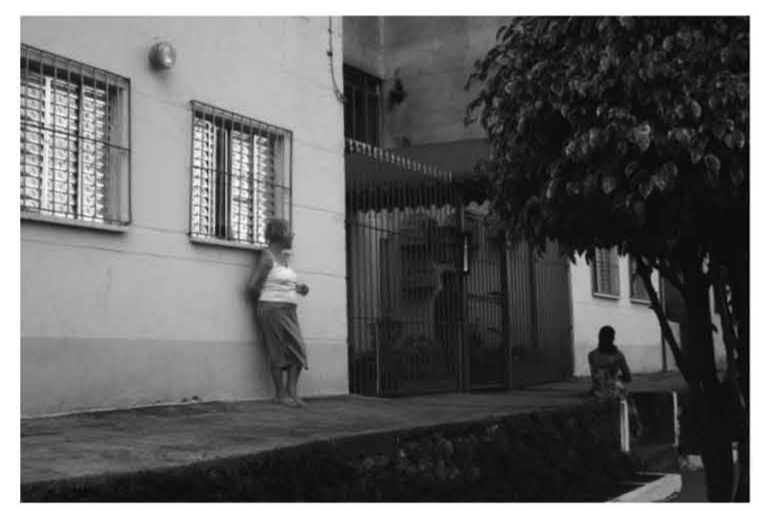

Fig. 5 Lack of gathering points and sitting places ${ }^{\text {vii) }}$

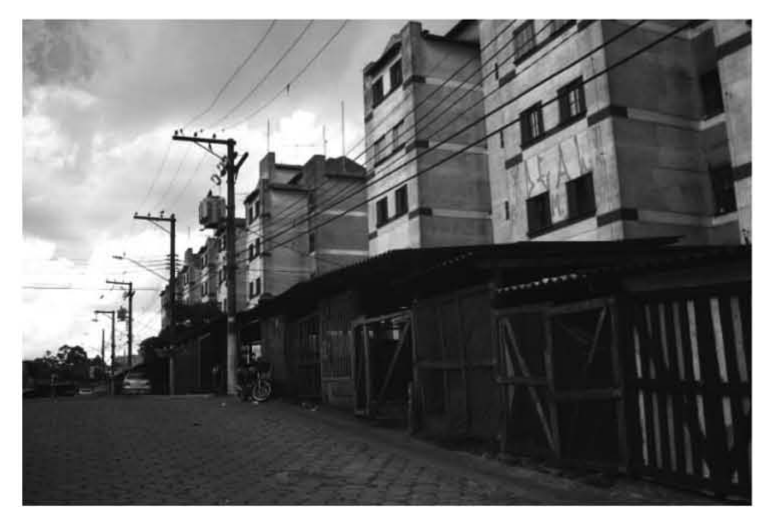

Fig. 6 Improvised fenced garages ${ }^{\text {viii) }}$

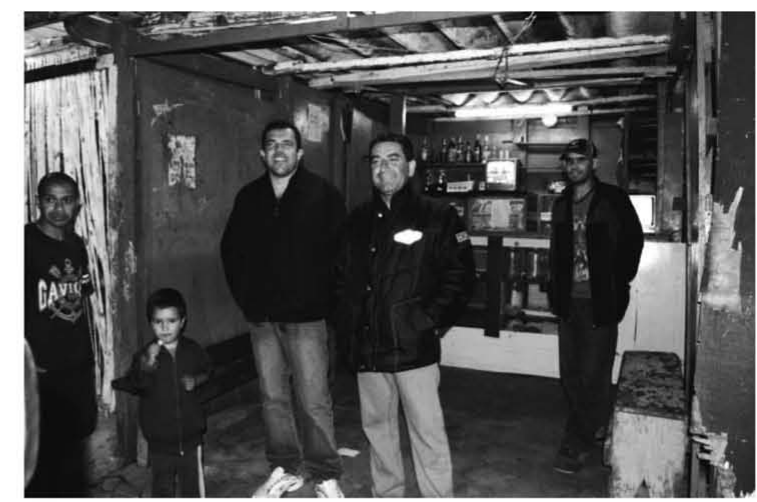

Fig. 7 Improvised bar

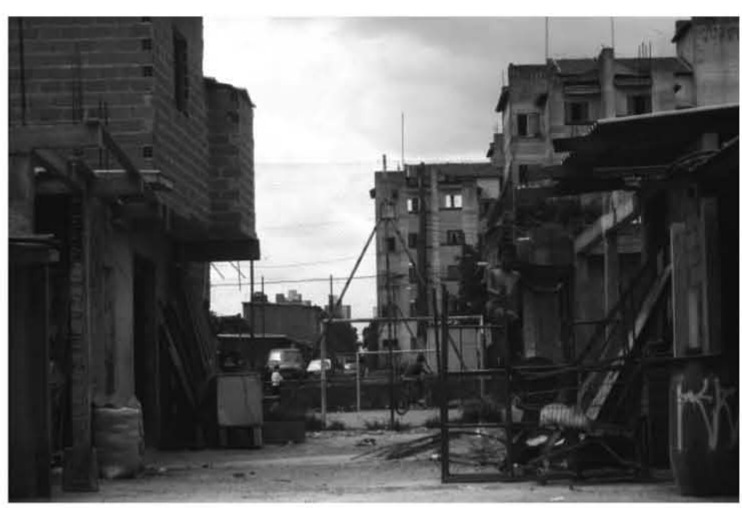

Fig. 8 New constructions in the open spaces of the developmentix)

\subsection{Survey - How the Residents Use their Open Spaces}

A survey was carried out in Heliópolis L2 Housing Estate to understand the residents' background, their satisfaction with the apartments, the design, facilities, accessibility and safety of open spaces, the intimacy amongst the residents, how they use their open spaces and their interest in social activities. It was carried out on a summer weekend in 2008 between 1 and $3 \mathrm{pm}$. 50 questionnaires were distributed and there were a total of 38 returns. There were 14 multi choice questions and a space for comment at the end of the survey.

Table 2 Survey

\begin{tabular}{|c|l|l|}
\hline Question & Answer Options & Result \\
\hline \multirow{4}{*}{ Age } & a - Younger than 18 & $23.7 \%$ \\
& b - Between 18 and 35 & $47.4 \%$ \\
& c - Between 35 and 65 & $28.9 \%$ \\
& d - Older than 65 & $0.0 \%$ \\
\hline \multirow{2}{*}{ Gender } & a - Male & $76.3 \%$ \\
& b - Female & $23.7 \%$ \\
\hline \multirow{5}{*}{ Apartment } & a - very bad & $2.6 \%$ \\
design & b - bad & $13.2 \%$ \\
& c - satisfactory & $34.2 \%$ \\
& d - good & $50.0 \%$ \\
& e - very good & $0.0 \%$ \\
\hline \multirow{5}{*}{ Open space } & a - Very bad & $57.9 \%$ \\
design & b - Bad & $13.2 \%$ \\
& c - Satisfactory & $7.9 \%$ \\
& d - Good & $21.1 \%$ \\
& e - Very good & $0.0 \%$ \\
\hline
\end{tabular}




\begin{tabular}{|c|c|c|}
\hline $\begin{array}{l}\text { Facilities in } \\
\text { the open } \\
\text { spaces }\end{array}$ & $\begin{array}{l}\text { a - Very bad } \\
\text { b- Bad } \\
\text { c - Satisfactory } \\
\text { d - Good } \\
\text { e - Very good }\end{array}$ & $\begin{array}{l}39.5 \% \\
36.8 \% \\
7.9 \% \\
13.2 \% \\
0.0 \%\end{array}$ \\
\hline Time & Number of times per week spent in the open & 3.29 \\
\hline $\begin{array}{l}\text { Time spent } \\
\text { at night in } \\
\text { the open } \\
\text { spaces }\end{array}$ & $\begin{array}{l}\text { a - No } \\
\text { b - Yes, but I prefer day time } \\
\text { c - Yes and I prefer night time } \\
\text { d - Yes and it doesn't matter whether it's day }\end{array}$ & $\begin{array}{l}7.4 \% \\
13.2 \% \\
28.9 \% \\
10.5 \%\end{array}$ \\
\hline $\begin{array}{l}\text { Accessibility } \\
\text { for elderly } \\
\text { or physically } \\
\text { disabled } \\
\text { people }\end{array}$ & $\begin{array}{l}\text { a - Not accessible at all } \\
\text { b - Not accessible } \\
\text { c- Satisfactory } \\
\text { d - Accessible } \\
\text { e - Very accessible }\end{array}$ & $\begin{array}{l}6.8 \% \\
29.5 \% \\
50.0 \% \\
9.1 \% \\
2.3 \% \\
\end{array}$ \\
\hline $\begin{array}{l}\text { Safety of the } \\
\text { open spaces }\end{array}$ & $\begin{array}{l}\text { a - Very unsafe } \\
\text { b - Unsafe } \\
\text { c - Not unsafe and not safe } \\
\text { - - Safe } \\
\text { e - Very safe }\end{array}$ & $\begin{array}{l}7.9 \% \\
15.8 \% \\
10.5 \% \\
60.5 \% \\
5.3 \% \\
\end{array}$ \\
\hline $\begin{array}{l}\text { Length of } \\
\text { residence }\end{array}$ & $\begin{array}{l}\mathrm{a}-\text { Between } 0 \text { and } 3 \text { years } \\
\mathrm{b}-\text { Between } 3 \text { and } 6 \text { years } \\
\mathrm{c}-\text { Between } 6 \text { and } 9 \text { years } \\
\mathrm{d}-\text { More than } 9 \text { years }\end{array}$ & $\begin{array}{l}5.3 \% \\
5.3 \% \\
7.9 \% \\
81.6 \%\end{array}$ \\
\hline $\begin{array}{c}\text { Relationship } \\
\text { to } \\
\text { neighbours }\end{array}$ & $\begin{array}{l}\text { a - I don't know any of them } \\
\text { b - I know a few of them } \\
\text { c - I know most of them }\end{array}$ & $\begin{array}{l}2.6 \% \\
23.7 \% \\
73.7 \%\end{array}$ \\
\hline $\begin{array}{l}\text { Intimacy } \\
\text { with } \\
\text { neighbours }\end{array}$ & $\begin{array}{l}\text { a - I know them by sight } \\
\text { b - I know them by name } \\
\text { c - I know them well } \\
\text { d - They are my friends }\end{array}$ & $\begin{array}{l}5.3 \% \\
39.5 \% \\
10.5 \% \\
44.7 \% \\
\end{array}$ \\
\hline $\begin{array}{l}\text { Type of } \\
\text { activities in } \\
\text { the open } \\
\text { spaces }\end{array}$ & $\begin{array}{l}\text { a - Reading } \\
\text { b - Walking or doing exercise } \\
\text { c- Spending time with children or relatives } \\
\text { d- Talking with neighbours } \\
\text { e - Eating or drinking }\end{array}$ & $\begin{array}{l}5.3 \% \\
31.6 \% \\
7.9 \% \\
44.7 \% \\
10.5 \%\end{array}$ \\
\hline $\begin{array}{c}\text { Social } \\
\text { activities }\end{array}$ & $\begin{array}{l}\text { a - No } \\
\text { b - Yes, but only if I have to } \\
\text { c-Yes, I really like it }\end{array}$ & $\begin{array}{l}42.1 \% \\
5.3 \% \\
52.6 \%\end{array}$ \\
\hline
\end{tabular}

Below are some of the messages from the interviewees:

"Some areas should be renovated in order to look more beautiful."

"I do not like the open spaces of this development. All the parties have to be held at someone's apartment because there is no place for parties here."

"There is no place for recreation inside this development. I prefer to go out rather than spend my time here."

"I am not afraid of going to the open spaces within this development but I do not let my children go out at night because the police beat up whoever is outside when they are looking for criminals."

"There are not enough garages for cars."

"I like to play with my friends outside."

Age and gender amongst the interviewees were not evenly distributed. Almost half of them (47.4\%) were between 18 and 35 and $76.3 \%$ were male. The results suggest that Heliópolis L2 Housing Estate's open spaces are not welcoming to older or female residents.

Half of the interviewees find the design of apartments good; another $34.2 \%$ find it satisfactory. However, most of them were dissatisfied with the design $(71.1 \%)$ and facilities $(76.3 \%)$ of their open spaces. This dissatisfaction is seen in the low number of times per week they spend in their open spaces (an average of 3.29 times per week). Many of them (47.4\%) do not spend any time in their open spaces at night.

Half the respondents find accessibility for elderly or physically disabled people in the development satisfactory. However, none of them were over 65 or physically disabled. The absence of elderly or mobility impaired people in the open spaces of Heliópolis L2 Housing Estate is conspicuous. It indicates its open spaces are not accessible for the old or infirm and objective judgement verifies this.

Surprisingly, $65.8 \%$ of the interviewees find their open spaces safe. This is heavily influenced by the community that existed in the favela, and their length of residence in the development. Most interviewees (81.6\%) have lived in the development for over nine years allowing them to know each other well, $73.7 \%$ know most of their neighbours, and $44.7 \%$ consider their neighbours friends. Additionally, $44.7 \%$ of the respondents use their open spaces to talk with one another. These activities encourage casual surveillance and foster familiarity amongst residents ${ }^{10)}$. Permanence also plays an important role in increasing intimacy amongst residents, leading to a sense of belonging and feeling of safety. Moreover, residents are socially active: $52.6 \%$ of the interviewees attend social activities because they like to They are interested in socializing and solving the problems of their community. It is striking that residents of Heliópolis L2 Housing Estate have been able to forge a community for themselves, and find some measure of safety and comfort within the development.

\section{Conclusion}

It was clear that Cingapura Project's main effort focused on the most urgent needs of its low socio-economic population: the provision of formal housing and basic infrastructure. In fact, many families did benefit from the project in Heliópolis L2 Housing Estate, and residents are satisfied with their new apartments. The area from which the families came from was reclaimed into the fabric of the city and there was an improvement in the image of the neighbourhood with the construction of the new development. The residents' sociability and permanence in the new development allowed their community to stay alive.

On the other hand, the residents' dissatisfaction regarding their open spaces is reflected in their disused and neglected spaces. The activities that once took place in the open spaces of the favela now take place in private spaces such as the residents' apartments. The development improved its inhabitants' living conditions, but not their social lives.

Fenced car parks, windows protected with bars and gates at the entrance of the buildings show evidence of the residents' concern about safety. However, survey results demonstrate the opposite-residents of Heliópolis L2 Housing Estate find their open spaces safe. The physical isolation of the development protects it from outsiders, which means most people found in its open spaces are members of the community. However, the same boundaries that protect the development hinder the residents' access to services and facilities available in other parts of the city. Despite the feeling of safety, the layout of the buildings onto the development site gave priority to the provision of roads and car parking spaces, making the open spaces inhospitable. The resulting long, wide roads enforce the feeling of emptiness 
and the presence of cars discourages the residents from using the development's open spaces, especially children, due to safety reasons.

In addition, Heliópolis L2 Housing Estate's open spaces were poorly designed and their current conditions do not encourage its residents to use them. There is a need for gathering points, green areas, recreation places, furniture, facilities and amenities (water fountains, toilets and sheltered spaces) that would encourage people to stay longer outdoors. Children too, are victims of the lack of furniture in the open spaces of the development. They need a safe and interesting place to play. Furthermore, a good quality community centre is necessary to develop social activities and encourage collective responsibility. Residents need a proper sheltered space where they can meet to discuss the issues of the development, or hold social events.

Furthermore, Heliópolis L2 Housing Estate is clearly not accessible to people with physical disabilities. Adaptations for disabled people would make the spaces more comfortable and benefit everyone. The provision of good quality open spaces and the transition between spaces from private to public is essential to foster healthy and sociable communities since housing developments with strong communities are better maintained and organized.

The construction of fenced garages and the development of new shanty housing in the development's open spaces led to a quick degradation of its communal spaces. This degradation was aggravated by the little attention given to the durability and maintenance of the project and high rates of default on rent and bills. Like in all Cingapura Project developments, the implementation of Heliópolis L2 Housing Estate did not allow for the integration of the development's inhabitants into the city's economy. Cingapura Project failed in providing opportunities for the financial support of its residents, and for the sustainability of the developments as a result of the single use given to its developments. Consequently, illegal businesses flourished in the improvised constructions of Heliópolis L2 Housing Estate deteriorating even more its open spaces. Residents struggle to maintain their social life in the new development.

While the provision of formal housing and basic infrastructure is the main target of most public housing developments, it is imperative to consider the economic and social conditions of their inhabitants. Finally, the sustainability of a housing development is founded on the sustainability of its community and vice versa. The result is a long term investment not only in housing but in improving the quality of life in urban areas.

\section{Acknowledgements}

The authors would like to thank Simone Okamori for conducting the survey in Brazil and her photographs, the residents of Heliópolis L2 Housing Estate for their collaboration in the survey and many other people without whom this research would not have been possible. The authors are also very grateful to Matthew Radich for kindly proofreading this paper.

\section{Notes}

i) Planning Department of São Paulo City http://sempla.prefeitura.sp.gov.br/infocidade/

ii) Housing Department of São Paulo City http://www.prefeitura.sp.gov.br/cidade/secretarias/habitacao/noticias/?p=4273

iii) In 2006, a list of 59 Cingapura Project developments was published in research by S. Rodrigues in São Paulo (Ref. 13). Some of the projects have no information linking them to Cingapura Project or were not built. The projects that matched those supplied by the Housing Department of São Paulo City are listed in table 1.

iv) Planning and Housing Department of São Paulo City http://sempla.prefeitura.sp.gov.br/infocidade/ http://www.habisp.inf.br/

v) The single residential use given to Cingapura Project did not allow commercial activities in the developments. However, due to the lack of shops or supermarkets at walking distance from Heliópolis L2 Housing Estate, illegal businesses flourished in its open spaces.

vi) Courtesy of the Housing Department of São Paulo City

vii) Photo: Simone Okamori

viii) Photo: Simone Okamori

ix) Photo: Simone Okamori

\section{References}

1) Abiko, Alex Kenya: Introdução à Gestão Habitacional, Escola Politécnica da USP Departamento de Engenharia de Construção Civil, São Paulo, 1995.

2) Abiko, Alex Kenya; Pereira, Priscila Maria Santiago: Conjuntos Habitacionais em Favelas de São Paulo: O Projeto Cingapura, São Paulo, 2002.

3) Apuzzo, Gian Matteo: Urban Communities and Participation in the XXI Century: The Informal Urban Century, Leuven and Brussels 2001.

4) Arantes, Pedro; Fix, Mariana; Tanaka, Giselle M.: The Case of São Paulo, Brazil, Understanding Slums, Case Studies for the Global Report on Human Settlements 2003, London, 2003.

5) Bonduki, Nabil: Origens da Habitação Social no Brasil: Arquitetura Moderna, Lei do Inquilinato e Difusão da Casa Própria, Estação Liberdade, São Paulo, 4th edition, 2004.

6) Cities Alliances: Integrating the Poor: Urban Upgrading and Land Tenure Regularization in the City of São Paulo, Cities Alliance Publications, 2004.

7) Gehl, Jan: Life Between Buildings: Using Public Space, The Danish Architectural Press, 5th edition, Copenhagen, 2001.

8) Ito, Viviane Raquel: Open Spaces in Public Housing in Brazil and Japan: Case Study of Cingapura Project in São Paulo and Public Housing Developments in Ibaraki Prefecture, Chiba, 2008.

9) Ito, Viviane Raquel; Kwak, Dongyn; Kitahara, Toshio: Children's Drawings of the Environment in Brasilia and São Paulo, Brazil, Chiba, 2010.

10) Jacobs, Jane: The Death and Life of Great American Cities, Modern Library Edition, New York, 1993.

11) Marques, Eduardo; Saraiva, Camila: A Dinâmica Social das Favelas da Região Metropolitana de São Paulo, Seminário Sobre Estrutura Social e Segregação Espacial, São Paulo, 2004

12) Rodrigues, Arlete Moysés: Moradia nas Cidades Brasileiras, Editora Contexto, São Paulo, 1988

13) Rodrigues, Soraya: Casa Própria ou Apropriada? Duas abordagens: O FUNAPS Comunitário e o Projeto Cingapura, São Paulo, 2006.

14) Taschner, Suzana Pasternak: Favelas e Cortiços no Brasil: 20 Anos de Pesquisas e Políticas, Cadernos de Pesquisa do LAP, No. 18, FAU - USP, São Paulo, 1997.

15) UN-Habitat: The Challenge of Slums: Global Report on Human Settlements 2003, Earthscan Publications Ltd, London 2003.

\section{和文要約}

シンガプーラプロジェクトは、ブラジル・サンパウロ市のファヴェ ラやスラムの問題を解決しようとし、結果として成功しなかった例 である。シンガプーラプロジェクトの取り組みは、貧民街の非物理 的な側面を考慮せずに、低所得者層にとって最も緊急性の高い要求 を満たすに焦点を当てた。シンガプーラプロジェクトのオープンス ペースは、生活環境や、社会的コミュニティの発展に寄与していな い。また当該地区と周辺部との融和や、都市と住民の関係を構築す ることに寄与していない。 